\title{
The Radiality of the Railway Network in Spain during its Early Stages (1830-67): An Assessment of its Territorial Coherence
}

\author{
Jaume Martí-Romero $^{1}$, Adrià San-José ${ }^{2}$ and Jordi Martí-Henneberg ${ }^{3}$ (D) \\ ${ }^{1}$ Economist at the Barcelona Chamber of Commerce, ${ }^{2}$ Researcher at the Barcelona Institute for Global \\ Health and ${ }^{3}$ Full Professor of Human Geography at the University of Lleida \\ Email: marti.henneberg@geosoc.udl.es
}

\begin{abstract}
The initial period of construction of the Spanish railway network is often criticized for its radial structure, centered on Madrid. In this article, the authors describe the role of the state during the initial stage of railway network construction and confirm that although the political will to construct a centralist network certainly influenced its morphology, other social and economic criteria were also influential. With regard to the political motives behind the radial network, the authors argue that part of this interest could have come in response to perceived needs to strengthen the presence of the Spanish state throughout its national territory and to promote a process of state-building. Finally, it must be stressed that the central hypothesis of our article is that the radial structure of the network was a natural consequence of the strategic geographical position of the country's capital and of the distribution of economic activity within Spanish territory. The article proposes two methodological approaches for evaluating the extent to which the radial design of the network was justified, bearing in mind the locations of Spain's most productive regions. The results of these two exercises suggest that the radial configuration with which the Spanish rail network was originally designed probably arose naturally as a result of the distribution of economic activity within the country and of the relative advantage that this bestowed on certain regions due to their geographic position.
\end{abstract}

Keywords: Railways; Spain; 19th century; Radiality; State-building

\section{Introduction}

The suitability of the predominantly radial morphology of the Spanish railway network, centered on Madrid, which marked the beginning of the process of railway construction in Spain - and has continued more recently with Spain's high-speed train (AVE) - has been, and continues to be, the object of an intense debate between academics and politicians and also amongst public opinion. The following statement captured our attention and perhaps provides a good illustrative example of 
how some in the field of academia have criticized the initial radial structure of the Spanish rail network:

Our analysis reveals a long-term regularity: infrastructure policy in Spain has not been driven by the requirements of commerce and economic activity, but rather by the desire to centralize transportation around the political capital of the country. (Bel 2011: 5)

This is not the only criticism of the centralized logic and design of the railway network. Other examples can be found in seminal works written by academics of prestige in the field of Spanish history and economy, such as Jordi Nadal and Mateo del Peral. In the text that follows, we offer the reader a number of their reflections:

The railway model applied to Spain had to be shown, very soon, as inadequate to the domestic needs ... because of the radial design of the network, which did not respond at all to the needs of the Spanish economy. (Nadal 1975: 47-50)

The formulation of lines [after the General Railway Plan of 1870] did not solve the problem of excessive centrality of the network. (Del Peral 1979: 130)

Although it is reasonable for us to argue that Spanish railway policy has not been exempt from errors in the past, and that errors continue today, we believe that the criticism leveled at the radiality of the Iberian gauge railway network during the initial process of its construction has tended to be lacking in appropriate qualitative and quantitative arguments. Even if we accept that the only priority of the state was to connect the most important nuclei to Madrid to strengthen the political presence of the capital within the national territory and to promote its growth, it is not obvious to argue that the resulting radial structure necessarily runs contrary to the economic needs of the country. In fact, those who think it did should provide evidence to support their allegations that for political reasons certain connections received priority over others of greater economic interest. However, no such quantitative analysis is presented in any of the previously cited articles.

The main contribution of our work lies precisely in the fact that it adopts a quantitative focus and casts light on the question of what would have been the most suitable morphological for Spain's initial railway network. The novel element of this article is that it proposes a conceptual framework for the analysis of the railway network that had previously been absent from studies undertaken in Spain and other European countries. ${ }^{1}$ This consists of comparing the railway lines to which a social planner would have given priority with those finally included in the network that was constructed. ${ }^{2}$ Here, we propose two ways with which to carry out this comparison. The first consists of creating a gravity model capable of providing an indicator that approximates the importance of connecting each region to the rest. To put

\footnotetext{
${ }^{1}$ A similar methodology was used in Capel et al. (1972). Even so, the approach and the type of analysis used here differ significantly from those used in earlier research.

${ }^{2}$ When we speak of a "social planner," we refer to an economic agent who seeks to maximize social welfare by connecting the stretches of railway with the greatest economic importance.
} 
it simply, the model provides a magnitude of the "attraction" between different regions that is based on the level of economic development of each region and the distance separating it from other nuclei and their economic activity. ${ }^{3}$ The objective of the second approach is to complement the first. It incorporates into the analysis the fact that when connecting a region, this must not only be seen as a destination (based on its economic weight) but also as a passing place and an efficient center of distribution (based on its geographical position). It seems evident that-ceteris paribus-Madrid (or any other region in the center of the Iberian Peninsula) would tend to have a certain relative advantage over others (and especially those located in the corners of the country, such as Galicia, Catalonia, and Andalucía) as a center of distribution due to its central position within the country (and therefore to have more connections to the rest). ${ }^{4}$ Although this argument may seem relatively trivial, it is one that we have not seen used in any of the articles that criticize the initial radial design of the Spanish railway network.

In relation to the methodology and to the data used to answer the questions posed in this article, it is important to stress that two new databases have been created that consider Gross Value Added (GVA) at the regional level. The first database estimates GVA in Spain at the level of the judicial district for 1860. This was the year in which the process of constructing Spain's railway network was just beginning. The great level of disaggregation of regional economic activity allowed us to identify (with great precision) which geographic areas of Spain justified having a greater level of connectivity with the rest at a time when the national rail network had yet to be constructed. The second database contains harmonized GVA data for Spain, France, and Portugal presented at the regional level for the same year. As before, the logic behind using these data is to determine which Spanish provinces had the greatest and most urgent need to become connected to neighboring countries.

The objective of this article is to establish and discuss which railway connections deserved the highest priority and to compare these with the ones that were constructed. To do this, the study starts by providing a brief review of Spanish railway policy covering the first attempts at railway construction through until the approval of the General Plan for Railways (Plan General de Ferrocarriles), covering the period from 1830 until 1867. This article first provides readers with a description of the political and historical context of the period. It also clarifies the fact that the morphology of the Spanish rail network did not only respond to a political plan to connect the state capital to the rest of the national territory but that other economic and social priorities also shaped Spain's railway policy. In relation to this particular theme, we offer a novel line of research with respect to previous studies. As far as the political motivation behind the initial radial design of the network is concerned, we argue that this could — at least in part - have been aimed at strengthening the presence of the state (which was, at that time, very limited) throughout the

\footnotetext{
${ }^{3}$ We have not included an analysis of the added advantage of being a city with port infrastructure. This is a limitation to our analysis because a city with access to the sea would have been more susceptible to becoming an interesting center of distribution.

${ }^{4}$ In our analysis, we do not take into account the orography of the terrain. Although we understand that this is a limitation to our article as any plan for railway lines takes the relief of the terrain into account, it would be very difficult to incorporate this dimension into our analytical framework.
} 
whole territory and at promoting the process of state-building within Spain. Although the idea of the state constructing a transport network that would serve its political interests relating to its consolidation of power could be criticized as a criterion for railway policy, it could be that such a structure facilitated the task of introducing, promoting, and monitoring of a series of common policies and regulations for the whole national territory.

This article is organized as explained as follows. The second section contains a description of the existing literature. The third section describes the historical context and examines Spanish rail policy from its beginnings until the preliminary approval of the General Plan for Railways. In the fourth section, we describe the sources used and how we constructed the data employed in the article. In the fifth section, we present the methodology and describe the results obtained. The last two sections are dedicated to political and economic interpretations of the results obtained and to presenting the conclusions that can be drawn from the research conducted.

\section{Literature}

Some authors (Muñoz and Vidal 2001) have held that the role of the state in Spanish railway policy prior to 1914 was limited to establishing the rules for the railway system to guarantee both the delivery of a public service under optimum conditions and the finances of the companies providing it. In this article, we defend the view that the state was also able to influence the design of the network. This theory is supported by the great similarity between the scheme for the lines approved by the Cortes Generales in 1854 and the network that was in service during the initial phase of railway construction.

When we address this topic, we seek to enrich the angles from which railway history has been studied in Spain until now. In this historiography, it is important to highlight a number of milestones. In the first period, several works were written that jointly focused on the introduction and development of railways in Spain (Casares 1973; Wais 1974). During a second phase, Spain's main experts on economic history produced essays that sought to interpret the transformation of the country from the nineteenth century onward. In these works, the railway theme acquired great significance. A negative and critical interpretation of Spain's economic development was established in a seminal work by Nadal (1982). In these lines, according to Tortella (1973), the railways absorbed a disproportionate percentage of investment and, as a result, took funding away from industry. This interpretation, which was critical of the role played by railways, was based on the fact that their financing came from investment banks or credit unions, which became the main vehicles through which foreign capital was channeled. They financed themselves through the mechanism of issuing bonds and thereby managed to secure a certain amount of funding from national savings (Wündsch 2016). However, the financial crisis of 1866 compromised the balance sheets of the banks at a time when the railway network was still unfinished and unconnected and had not yet been able to generate significant profits. Most of the railway companies-the majority of which were still relatively small—suffered badly as a result of this situation and many of them went bankrupt and were absorbed by the largest railway companies. It was only after the passing of a new law governing railways, in 1877, that the rail 
network was able to grow again. This eventually gave rise to a railway oligopoly based on three major companies that dominated the previously consolidated territory: the Compañía de Caminos de Hierro del Norte (Norte), the Compañía de Madrid a Zaragoza y Alicante (MZA), and the Compañia de los Ferrocarriles Andaluces.

In general terms, this was the financial environment corresponding to the first phase of railway expansion. Although Tortella and Nadal both provided a negative vision of the railway and its influence in the nineteenth century, later work-carried out under the management of Artola (1978)_revised these theses based on a series of research that studied different aspects of the railway and its economic importance for Spain over the longer term. The chapter written by Artola highlighted the role of the state in the establishment of the network and in its regulation using concessions granted to private companies. His analysis gave rise to a more positive interpretation than earlier studies. In another chapter within the same work, Del Peral explained the different models that underlay the political positions taken by the progressive and moderate political parties. These political options influenced the legislative framework governing the railways that, as we shall see in the next section, is key to the general context of our article.

Later, the work of Gómez Mendoza (1982) showed that the railway played a fundamental role in the modernization of the Spanish economy. His initial hypothesis was based on a counterfactual analysis: What would have happened if the Spanish economy had not had the railway? His answer was that due to the impossibility of using alternative means to meet the demand for transport, if the railway network had closed in 1878 or 1912, this would have resulted in the respective losses of 2.5 percent and 24 percent of social savings in relation to GNP (Gross National Product). This analysis led to the railway being seen as an indispensable service, sharply contrasting with the earlier negative visions.

From this point on, a large number of analyses were conducted at the regional level. In particular, these focused on the Basque Country (Ormaechea 1989), Catalonia (Pascual 2017), and the Community of Valencia (Hernández and Martínez 1983). This new tendency was related to the political changes that took place in Spain following the introduction of the Constitution of 1978. This marked the beginning of a period characterized by the devolution of political power to newly created autonomous regions that, in turn, promoted studies of their territories across a wide range of different fields. Even so, global studies of the history of Spain's railways still continued to be published, as did works focusing on other aspects related to their economic and demographic importance. In the following text, we shall identify the bibliographical sources that have been used as references for our article. As will be seen, they cover a wide range of different topics.

We started by examining original official texts and studies of railway legislation that we examined within the political context of the period (Frax 1996; Olmedo 2001; Ortúñez 2016). These references provided the base for interpreting studies that deal with the political component of designing Spain's terrestrial transport network. Here, the work of Bel (2011) was one of the main points of reference that our research sought to contrast. Bel made an implacable critique of the centralist vision that led to Spain having predominantly radial networks for both its road and railway transport. This vision has been complemented by using other, more empirical, 
studies revealing the role of the distribution of agricultural activity for interpreting the morphology of the road (Pablo-Martí et al. 2020) and the railway networks (Barquín 2009; Cuéllar 2007) and its financial considerations (Ortúñez 2016). It is also important to mention works that, at their time, proposed an ideal model for Spain's railway network (Equipo Urbano 1972) and produced a theoretical essay about the form of Spain's rail network (chapter in the book by Artola 1978). More recently, other publications have studied the role played by the Ministry of Public Works (Cuéllar 2002) and by civil engineers (Ferri 2015) as essential agents for the construction of the national railway network.

Another area taken into consideration by our article was that of studies relating to the distribution of economic activity in Spain, whose historical analysis at the regional level is one of the best developed in the whole of Europe (Beltrán et al. 2016; Martínez-Galarraga 2012; Martínez-Galarraga et al. 2015; Rosés et al. 2010; Tirado et al. 2016). This provided the foundation for designing our model. This was based on GDP data for 1860, although the data refer to more detailed units, such as judicial districts (Esteban-Oliver 2017; using data provided by F. BeltránTapia). It must be underlined that no previous studies had been made into the impact of the railway on the uneven growth of GDP within Spanish territory. What was available on this subject can be found in a wider study of the whole of Western Europe (Martí-Henneberg 2013). There were, however, previous studies that quantified the impact of the railway on the distribution of population (AlvarezPalau et al. 2013; Morillas-Torné 2014) and, more specifically, in the fields of urbanization (Mojica and Martí-Henneberg 2011; Barquín et al. 2012; Enflo et al. 2018) and economic impact (Herranz-Loncán, 2006). These works show that the railway favored the concentration of population in certain specific places-particularly urban areas-while others became depopulated. However, in the latter cases, the railway also helped to retrain population in areas relatively near to stations. These conclusions referring to population show that the railway contributed to the concentration of economic activity and-as a result-to the creation of new regional disparities.

Looking at the scope of these background studies of the impact of the railway network, it is evident that this article focuses on themes that had not been addressed before. It seeks to compare the railway lines to which a social planner would have given priority with the network that was finally constructed. This has allowed us to analyze the rationality of the Spanish railway network during its initial process of construction using quantitative arguments and to question the historical accusation that the morphology of the network was the result of it having been built without considering the economic needs of the country.

To finish this section, it is necessary to underline that this article has been written out of an interest in interpreting the contribution that the railway network made to the process of state building. To find reference works following this line, it was necessary to look for studies carried out in other countries. The one that has served as our best reference was by De Block (2011) and relates to Belgium. This work reconstructed the design of a railway network by the new state of Belgium to integrate the interior of the country and to provide suitable connections with the exterior. This was of great importance for a small country occupying a highly strategic position. In the case of Spain, the preoccupation with international connections was initially 
much smaller. It did, however, gradually gain greater importance from the $1860 \mathrm{~s}$ onward, when it became evident that the European network had become consolidated. Following this line, several notable works have studied Spain's cross-border connections with both Portugal (Pinheiro 1995; Pereira and Peto 2012; Pereira 2017) and France (Vidal 1999).

To put this article into context, an important amount of attention has also been given to studies of state building in Europe, a process that - to date-has mainly been approached from the fields of sociology (Flora 1973, 2016), history and political science (Hirsch 2003; Elden 2007; Teichova and Matis 2003; Ardant and Charles 1975). Following this line, we find works that refer to the intellectual influence of SaintSimonian thinking at the time when the railway network was being constructed to be of particular relevance. In fact, the French railway expert Teisserenc de Bortwho at the time was one of the most conspicuous defenders of such argumentsinsisted on the need to limit the extension of the railway network. He believed that it should cover the real needs of the country and aim to use common trunk routes to economize on the use of resources. He similarly defended promoting the principles of equity, which - in his opinion - called for generalized access to public services and the need to guarantee a carefully measured use of public resources. This was a very modern outlook and one that influenced the orientation given to the promotion of railway networks in various European countries, including Spain.

The next section establishes the historical context and explains Spanish railway policy between 1830 and the end of the 1870s.

\section{The Role of the State in the Initial Configuration of the Spanish Railway Network (1830-67)}

In the first section, we describe the historical context and the passive role adopted by the Spanish state during the initial phase of planning and constructing the national railway system. We then explain the main priorities that initially shaped the course of Spanish railway policy. After that, we highlight the principles that were followed after the initial phase of construction and explain how the state subsequently modified the order of its priorities (substituting a radial network for another, more integrating, logic) as the process of railway construction gradually advanced. In the third section, we will analyze whether the radial design was linked to a desire to promote the process of state-building within Spain's national territory.

\section{From partial concessions to the adoption of a global vision of Spain's railway network}

At the beginning of the nineteenth century, Spain was a poor country in comparison with other European powers. The relatively late development of its railway system further highlighted the country's economic and technological backwardness with respect to other regions of Europe. As table 1 shows, while the United Kingdom, Germany, and France already had more than 14,000, 10,000, and 8,000 kms of railway track in service respectively by 1860 , Spain had only built $1,000 \mathrm{kms}$ at that time. Much of this backwardness has been attributed to the weak position of the Spanish economy and the country's political context (Del Peral 1979: 164; Tortella 1973). 
Table 1. Railway development for selected European countries in 1860

\begin{tabular}{lcc}
\hline & Total KMs & Railway density* \\
\hline United Kingdom & $14.231,7$ & 65,0 \\
\hline Germany & $10.833,2$ & 19,9 \\
\hline France & $8.469,3$ & 15,9 \\
\hline Italy & $1.957,3$ & 19,7 \\
\hline Belgium & $1.618,7$ & 54,7 \\
\hline Spain & $1.012,0$ & 2,0 \\
\hline
\end{tabular}

${ }^{\star}$ Railway density is defined as the amount of railway kilometers built in a certain region divided by its area. Source: Author computations based on http://europa.udl.cat/projects/european-railways/.

Between the years 1830 and 1844 , the state merely acted as a receiver of requests. The first concessions were awarded in the regions of Andalucía and Catalonia, although these lines finally failed to materialize due to the lack of state support. This can be partially explained by the fact that the Regency of María Cristina (1833-40) was-politically speaking-a very convulsive time, with constant changes of government as well as the additional problems caused by the First Carlist Civil War (1833-39).

From 1844 onward, however, the advances being made were clearer. There is evidence of interest in providing rail connections to some of the most important cities in Catalonia and Andalucía, which were two of the regions with the highest levels of economic development at that time. The state therefore granted Barcelona businessman José María Roca a license for what was to be the first railway line in Spain. This was completely funded by private capital and connected Barcelona to Mataró in 1848. In 1845, the state also awarded a license for the Madrid to Aranjuez (where there was a Royal Palacio) line. This concession was a source of considerable controversy given its more than questionable viability and the economic contribution of the state to the building of this stretch of line.

Initial railway policy was therefore characterized by a certain degree of disorder and arbitrariness with respect to the concession of new lines. There was no official commission to evaluate projects and the administration lacked the experience required to adequately evaluate large-scale private initiatives. All this made the state more aware of its need to become more directly involved in the process of building the railway network. The Royal Decree of 1844 was passed with the aim of providing a common legal framework that would serve as a point of reference for those obtaining licenses. It detailed the rules and general requisites that railway companies should meet. It is, however, important to underline that although Spain clearly expressed its strategic interest in building a railway network, its role continued to be limited to that of receiving private requests.

From the moment that the Royal Decree came into force, the number of concessions shot up $(6,500 \mathrm{~km}$ of track in two years), although only a total of $186 \mathrm{~km}$ was built, largely because of the noninterventionist stance of the state. This situation highlighted the need to create a more ambitious and clearer regulatory framework with respect to the role that the state should play in designing and 
providing financial support for the railway network. With this in mind, two new projects for general railway law were drawn up and were known as the Bravo Murillo (1848) and Seijas Lozano (1850) projects. They both helped to establish much clearer criteria for public subsidies and other state aid that had not been laid out in the Royal Decree of 1844.

Although neither of these two initiatives was crystallized in the passing of a general law on railways, it is relevant to underline their relevance to, and influence on, the Law of 1855 . They were the first proposals to offer a hierarchization based on the importance and nature of railway connections. Another point in common shared by the two proposals was that they were the first legislative attempts to contemplate a certain degree of administrative planning and to adopt a global vision for the design of the railway network. They gave the state a much greater role and far more responsibility in the task of defining the railway network than it had hitherto assumed.

\section{The Motivations of the State in the Initial Design of the Spanish Railway Network (1850-67)}

In 1850, Spain only had $26 \mathrm{kms}$ of railway track in service. This relative backwardness with respect to other countries, combined with the evident shortcomings exhibited by the system of concessions in the previous five-year period, led to a reconsideration of what was required and indeed possible. The role of the state as a receiver and regulator of requests was abandoned in favor of it taking a more proactive and interventionist role. A good example of this new position was evident in the passing of the General Law of Railways (1855) and the General Plan of Railways (1867). The aim of passing these two legislative texts was to clarify the preferences of the state with regard to establishing new railway lines and to reduce uncertainty with regard to the provision of subsidies and thereby attract sufficient foreign capital to fund new initiatives.

It must be underlined that the years between 1850 and 1867 were marked by an intense debate about which railway connections were the most relevant. In fact, one of the most controversial questions discussed concerned the radial structure with which the Congressional Commission and the majority of the proposals initially foresaw the design of the network. By way of illustration, the Spanish Parliament approved the basic layout for the railway network in 1854, which we reproduce in figure 1 . This proposed building two lines to that would connect Madrid to France and Portugal, respectively passing through Irún and Badajoz. It also approved a connection between Madrid and Cartagena, with a stop at Albacete. A third line was projected to Barcelona, with a stop at Zaragoza, which would also connect with the northern line. A fourth line was to connect Madrid with the south of the peninsula, ending in Cádiz and with a branch line to Málaga. Finally, there was a proposal to build a line to the port of Santander, with a connection to northwest and Galicia.

When the state became actively involved in railway design, in the 1850s, the majority of the proposals were therefore already based on a centralist conception of the network. The main reason for this was the priority given to connecting Madrid to the main nuclei of production, the Mediterranean and Atlantic ports, and the two neighboring countries. Initially, the argument in favor of the centrality of the network was based on an interest in satisfying the consumption needs of the 


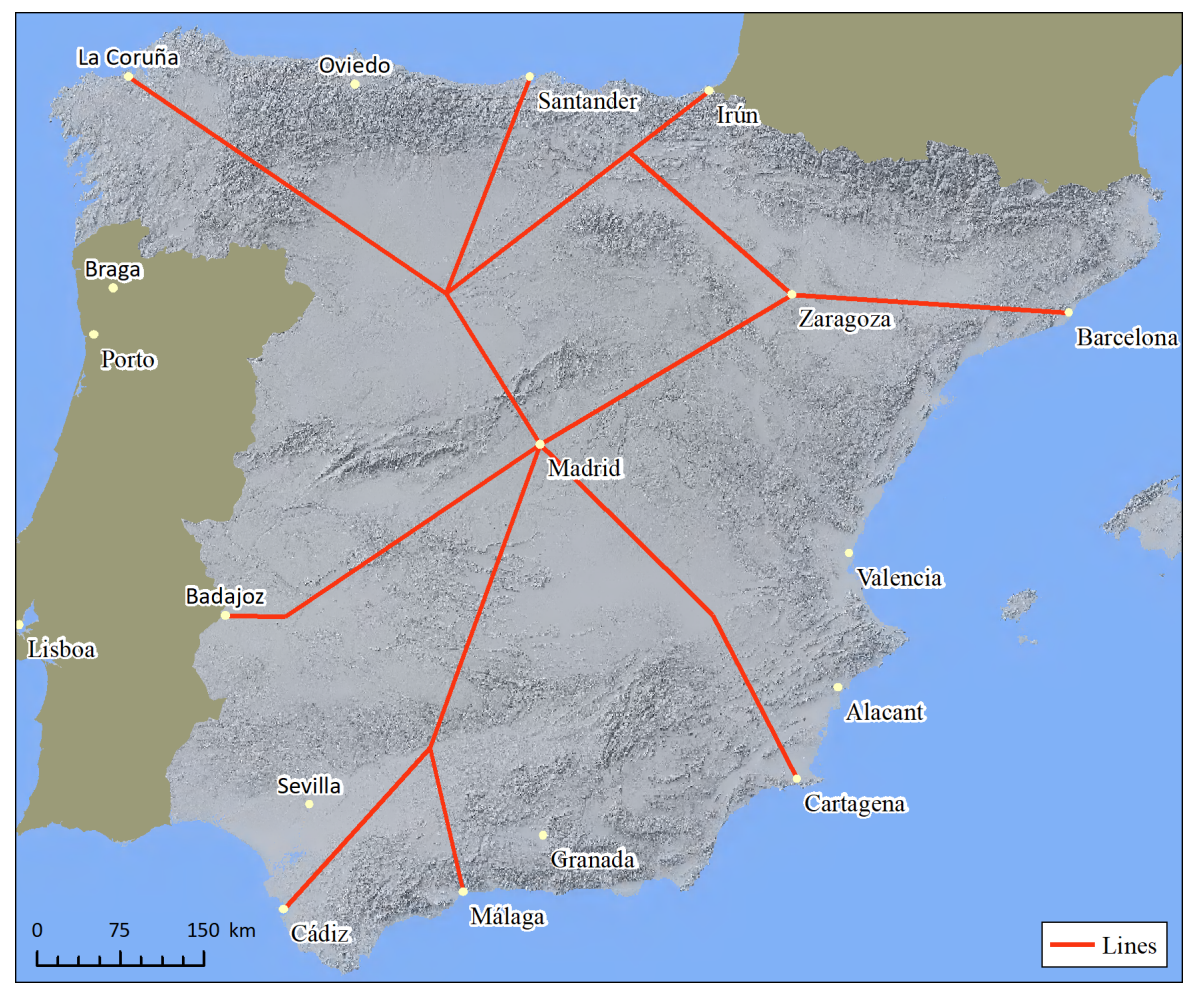

Figure 1. Railway priority lines approved by the Spanish Parliament in 1854.

Source: Del Peral (1978: 91).

capital (Del Peral 1979: 56). An associated aim was to put an end to the progressive isolation that Madrid had suffered during the first phase of railway construction based on private initiatives, during which it had only been proposed to build short stretches connecting important nuclei of production (especially in Catalonia and Andalucia). Although this centralist mentality is widely documented in the literature, it is necessary to underline that the state also incorporated other criteria into what was to be the definitive design of the basic railway network (Bel 2011). These were economic, strategic, and redistributive in nature and based on promoting greater territorial cohesion, as we argue in the following text.

The decision to establish a radial network centered on Madrid was not only political but also based on economic criteria. This is shown by the proposal that Mariano M. de Reinoso (1851) drew up and presented in parliament prior to the approval of the General Law of Railways. It suggested that a centralist network of railway lines would be also coherent with the economic interests of the country:

The project does not recognise any more than a single concentric point of origin: Madrid; the lines will follow the paths dictated by the flows of production, traffic and international policy. (Del Peral 1979: 74) 
Similarly, before the approval of the General Law of Railways, the Parliamentary Commission expressed its concern to dynamize the richest regions in the territory and declared that the network should provide the country "as soon as possible with the railway lines that were urgently called for to meet the needs of industry, agriculture and commerce" (ibid: 90). Additionally, during the elaboration of the General Plan of Railways, it was also understood that this radial structure should be complemented with infrastructure that would connect the whole of the country for economic purposes. A good example of this is provided by the Junta Consultiva de Caminos (Consultative Board of Routeways) that declared that the construction of transversal routes (those built without connections to Madrid) was essential to facilitate traffic between "the rich deposits and industrial focus which would make it possible to dynamise communications between very distant settlements" (ibid.: 110).

Another principle that influenced the morphology of the Spanish railway network was the consideration to attend the most disfavored regions, particularly Galicia. For instance, Mateo Sagasta, a very influential politician and engineer who contributed to the initial design of the railway network, noticed that the route from Madrid to Vigo was essential to attend a very important social need (ibid.: 94). Additionally, this view was also present when the General Plan of Railways was being conceived, as it incorporated several articles that were based on the "leveling principle" of the engineer José Echegaray, who had called for the construction of transversal lines. His objective was to compensate the poorest provinces and, in this way, to overcome "the scandalous disparities" between the different regions of the country (ibid.: 124).

Finally, another important criterion that influenced the initial design of the network included the strategic motives of the kingdom, looking to both the interior and exterior connections. In the former case, it was necessary to connect the interior of the country-and in particular Madrid - to the most important seaports. The clearest example of this was the previously mentioned line from Madrid to the port of Cartagena, whose construction was proposed for military reasons. In the latter, external strategic considerations called for a northern route leading to France and a line to the Portuguese border, passing through Irún and Badajoz, respectively.

In short, between 1830 and 1867, the role of the state in relation to railway policy was gradually adapted to satisfy the needs of the economic and political contexts. It changed from simply approving specific requests to adopting a more proactive and interventionist position, within a legislative and regulatory framework that promoted private investment. Finally, it is necessary to underline that although the state initially adopted a rather centralist mentality when it came to designing the railway network, it also took into consideration many other factors that it deemed to represent the global interests of the country. For this reason, for the first time, the design of the railway lines set out in the General Plan of 1867 included the principle of territorial cohesion and compensation between the different regions of Spain.

\section{Railway Policy as an Instrument of State-Building in Spain}

Up to this point, we have described the origins of railway policy and the priorities according to which the state planned the national network. In this section, we will analyze another aspect that we think influenced the design of the network but that 
we have not seen discussed in the literature. We refer to how the desire to promote the process of state-building could have conditioned Spanish railway policy in the middle of the nineteenth century.

Until now, we have argued that the design of the Spanish railway network was influenced by a combination of political, strategic, and economic priorities. These included the objective of connecting Madrid to the country's main productive and strategic nuclei; connecting up its most important centers of production; and meeting other criteria of a more social nature, such as to promote greater territorial cohesion and equity. What we wish to analyze in this section, however, is whether the Spanish state could have used its railway policy as an instrument to promote its own political and institutional stability across the whole of the national territory. More specifically, we want to examine whether the radiality of the railway network was not only designed as a premise to satisfy the consumer needs of Madrid and prevent its isolation but also as a way of meeting the desire of the state to use railway policy as a tool for state-building.

As Bravo Murillo clearly explained in his proposal (1848), which provided much of the input for the Ley General de Ferrocarriles of 1855, the radial network sought to strengthen the role of the State throughout Spanish territory:

The iron roads are destined to change the conditions of States ... and to become powerful agents of administration and government, with whose help it will be easy for executive power to make its protective action or its severe hand felt in all corners of the kingdom at the same time, thereby establishing the cohesion and unity that constitute the centralization and real effective force in all the different parts of the State. (Del Peral 1979: 48)

This fragment concisely summarizes the will of the state to consolidate its political and administrative position throughout Spain's national territory and explains how the railway was presented as an essential tool for achieving this objective. From a present-day perspective, such a desire to connect the main center of political power to other regions of the country to consolidate territorial unity could be the object of criticism if it were used as the guiding principle of railway policy. However, given the political fragility of the Spanish state in the middle of the nineteenth century, this move no doubt fostered better communication between the state and its regional administrations. At the same time, this policy provided a useful tool for developing common policies between different regions of Spain and thereby promoted a greater degree of territorial cohesion.

\section{Data}

The databases that we describe in this section are new and have been constructed with the aim of providing answers to the problems and specific challenges posed by the present article. One of the fundamental objectives of the study is to analyze that regions of Spain most urged to be connected, both internally and externally (to France and Portugal). The assumption that we have used when carrying out this analysis was that the need for a given territory to be connected to the rest depends 
on its level of economic development and on the distance that separates it from other parts of Spain and/or neighboring territories.

To carry out this analysis, we put together two complementary data sources. The first is based on an estimation of GVA at the level of the judicial district for Spain in the year $1860 .^{5}$ The novelty of this database is precisely the fact that it provides a greater degree of territorial disaggregation of GVA. This is useful as it allows us to determine with greater precision which parts of Spain's geographical interior attracted each other with the greatest intensity. Secondly, as our objective is to extend our analysis to cover external railway needs, we also created a harmonized database of regional GVA for Spain, France, and Portugal relating to the year $1860 .^{6}$

In the following text, we detail the sources that we use to obtain the data and the methodology that we employ to calculate GVA for Spain at the judicial district level, as well as GVA for Spain, France, and Portugal at the province level for the year 1860 in both cases.

\section{The Estimation of GVA at the Judicial District Level in Spain, 1860}

It should be underlined that this database was created by combining information based on two different articles. Generally speaking, our work exploits data on worker productivity and sector-by-sector specialization (the number of workers in different branches of activity) to obtain an estimation of economic activity in Spanish territory in the mid-nineteenth century. We used the data provided by Rosés et al. $(2010)^{7}$ as an indicator of sectorial productivity per worker at the provincial level in 1860. Furthermore, to obtain a database for GVA at more disaggregated level than that of the province (459 judicial districts on mainland Spain), we included data on sectorial specialization at the judicial district level (Esteban-Oliver 2017). ${ }^{8}$ To obtain the GVA at the level of the judicial district we multiplied the sectorial productivity per worker at the province level by the total number of people employed in each sector at the judicial district level. For this calculation, we made the implicit assumption that sectorial productivity is the same across judicial districts within the same province. ${ }^{9}$ We provide the results in figure 2.

\section{The Estimation of Regional GVA in Spain, France, and Portugal, 1860}

We used data obtained from different sources to create an indicator of regional activity for Spain, Portugal, and France for the year 1860. To achieve this, we devised a methodology for harmonizing data to make them comparable.

\footnotetext{
${ }^{5}$ Until now, estimations of GVA at the province level have only been available for the year 1860 .

${ }^{6}$ Departaments in the case of France and Distritos in Portugal.

${ }^{7}$ Tirado et al. (2010) estimated sectorial productivity (for agriculture, industry, and services) per worker at the provincial level for the years 1860, 1900, and 1930 using the approach suggested by Geary and Stark (2002).

${ }^{8}$ The article provides the total number of workers employed in agriculture, industry, and services at the judicial district level, based on the 1860 census.

${ }^{9}$ Although we recognize that this is an important assumption, we think that the differences in productivity between judicial districts for a given sector and province were not great as they shared many idiosyncratic factors at the provincial level (relating to policies, climate, and culture, etc.).
} 


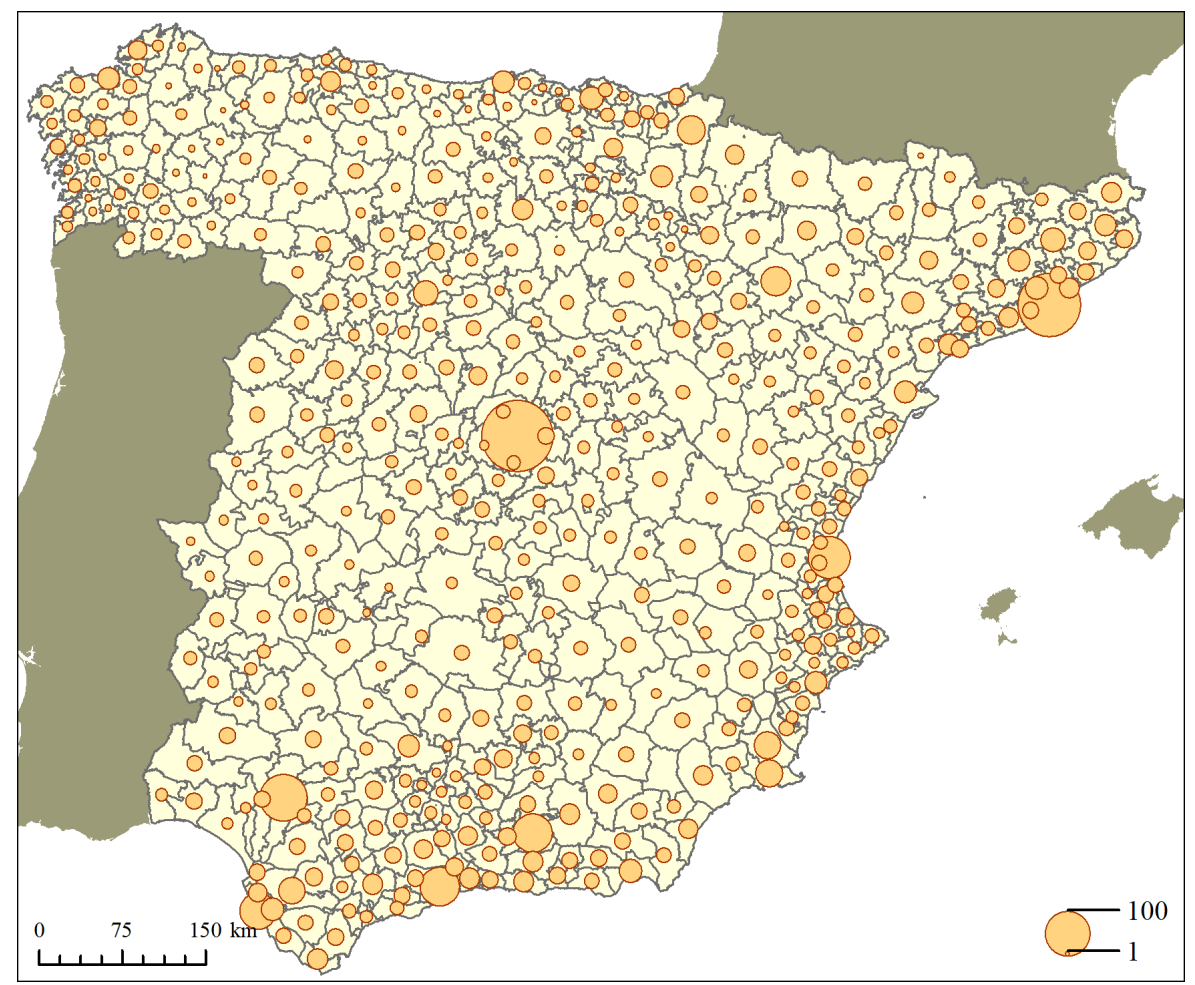

Figure 2. GVA for Spanish judicial parties in 1860, on base 100.

Source: Author computations based on Guillermo Esteban-Oliver (2017).

In the cases of Spain and France, we used the estimations of GVA at the regional level for the year 1860 made by Rosés et al. (2010) and Combes et al. (2011). In the case of Portugal, however, the task was rather more complicated. Although BadiaMiró et al. (2012) had made estimations of GVA at the regional level for the year 1890 , no such data were available for 1860 . To solve this problem and estimate GVA at the regional level for 1860 , we built a linear model that was common to all of the regions, ${ }^{10}$ except Lisbon and Porto, whose explanative variable is their total resident population. For the Lisbon and Porto regions, we used an exponential model due to the fact that it fits better with our data. This is because the exponential relationship captures agglomeration effects with a greater degree of accuracy.

Once we had obtained regional data for Spain, France, and Portugal for the year 1860 , the next step was to harmonize them to be able to compare different levels of regional activity between countries (figure 3 ). Two steps were needed to obtain harmonized data: adjusting for exchange rates and correcting price differentials between countries. To carry out these calculations, we relied on the estimations made by Prados de la Escosura and SanzVillarroya (1998).

\footnotetext{
${ }^{10}$ The linear model consists of a cross-sectional analysis for the year 1890 . The assumption that we make is that the linear relationship between population and GVA remained constant between 1860 and 1890 .
} 


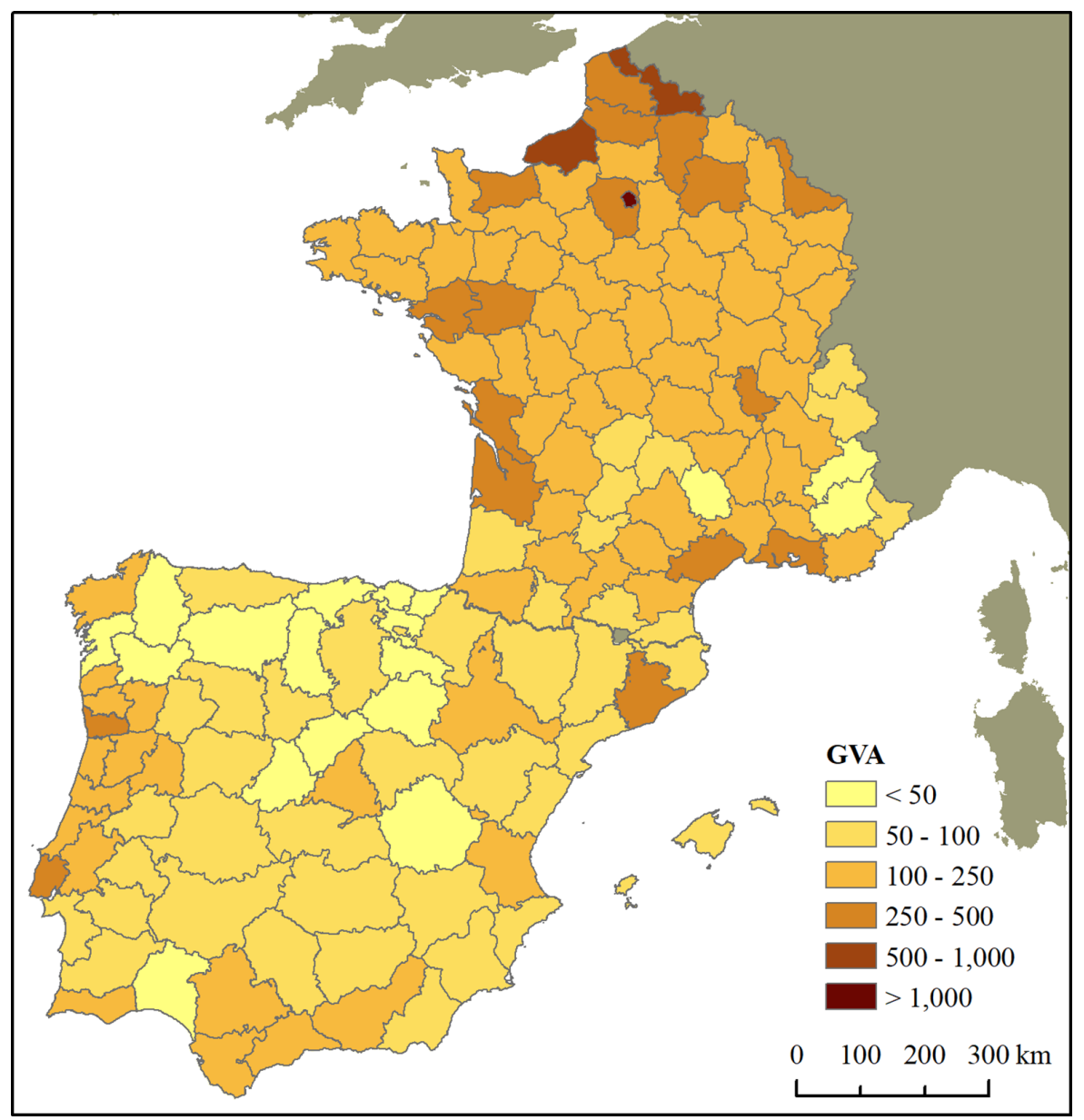

Figure 3. Regional GVA* for Spain, France, and Portugal, 1860.

${ }^{\star}$ GVA expressed in US dollars.

**Despite the fact that exchange rates and price differentials are considered to obtain harmonized data, our results need to be taken with a certain degree of skepticism. For instance, figure 3 shows that a significant share of Portuguese regions is more or less equally developed compared to Madrid in economic terms. Although these results suggest that regional GVA comparisons between countries could be misleading, we want to highlight that it does not influence our results regarding cross-border railway connections, as we impose a fixed number of connections from Spain to Portugal and France.

Source: Author computations based on Rosés et al. (2010), Combes et al. (2011), Badia-Miró et al. (2012), and Prados de la Escosura and SanzVillarroya (1998).

\section{Methodology and Quantitative Results: The Railway at the Service of the Economy-Two Simulations}

In this section we propose studying, using two theoretical exercises, the railway connections that should have been promoted by the state if it had only taken into account the geographical positions and economic weights of the different regions within Spain and outside the country (i.e., in France and Portugal). Comparisons 
between the results of our simulations and those of the network that was planned allowed us to analyze, with greater precision, the extent to which the planned network differed from what a central planner with the sole objective of connecting the points of greatest economic interest both within and outside the country would have chosen. We must remember that this is a case of trying to determine whether the policy chosen by the state, of promoting a centralized rail network, could - in facthave worked against the economic interests of the country. To do this, we used two complementary approaches: calculating the potential for economic interaction and the passing potential in the judicial districts.

\section{Estimation of Spain's Railway Requirements in 1860 Based on Potential Economic Interactions between Regions}

This calculation was carried out at two levels: between judicial districts in Spain and between regions within a wider area comprising France, Spain, and Portugal.

\section{Connections between Judicial Districts in Spain}

The first exercise consisted of applying a gravity model to obtain an idea of what should have been, from a purely economic point of view, the main priorities for establishing railway connections in Spain in 1860.

First, we estimated the potential for economic interaction $P_{i j}$ between any two regions $i, j$. We understand that this interaction reflects their economic complementarities in terms of the exchange of merchandise and services. It seemed reasonable to us to suppose that the probability of there being economic complementarities between two regions would depend on their GDP. In fact, between two regions with important economic weights there is a greater potential for economic interaction than between two with small weights, or between one with a large weight and another with a small one. This led us to the conclusion that $P_{i j} \propto P I B_{i} \cdot P I B_{j}$; in other words, that there would be a multiplier relationship between their GDPs, which would produce a dependence of the type described.

Furthermore, the distance between these regions would act as an obstacle to their economic interaction. As a result:

$$
P_{i j} \propto \frac{P I B_{i} \cdot P I B_{j}}{d(i, j)^{\alpha}}
$$

where $\alpha$ is an exponent that needs to be determined and $d(i, j)$ is the distance between what were the most populated nuclei of the regions used in 1860 .

The dependence of proposal $P_{i, j}$ can be captured by what are commonly known as gravity models. These models, which are inspired by Newtonian physics, have been widely used to describe interactions between people and flows of merchandise. The first person to suggest their use in the social sciences was the sociologist Henry Charles Carey (1793-1879), who argued that man was a molecule of society and that, as such, he was subject to a form of social interaction analogous to the gravitational one. A good historical review of the use of gravity models can be found in Philbrick (1973) and we would recommend this source to anyone with an interest in this subject. In this article, we have followed the model proposed by Stewart 
(1941) and Zipf (1946), who-individually-proposed an interaction with the following dependence:

$$
P_{i j}=\frac{P I B_{i} \cdot P I B_{j}}{d(i, j)}
$$

In the historical review presented by Philbrick (1973), it is easy to note the wide range of opinions relating to the exponent of distance, with the most widely used dependencies being its linear and quadratic forms. ${ }^{11}$ In fact, some researchers have gone as far as to propose that the exponent of distance should vary according to either the population (Anderson 1956) or distance (Carrothers 1956) involved. Whatever the case, in this article, we do not seek to get involved in a technical debate. Here, we decided to adopt the model described because it is one of the most commonly used and is one of the easiest to apply.

The gravity model described here always calculates the benefits of uniting all the GDP of one region with all of that of the other, taking into account the distance between the two regions concerned. It is, however, unreal to suppose that constructing a railway line between the densest nuclei of any two regions should easily connect all of the municipalities within the territories in question. There are evident problems of accessibility and the larger the size of the regions considered, the more considerable they become; as a result, it is preferable to work with units that are as disaggregated as possible. As previously mentioned, we worked with data at the level of the judicial district for Spain, but at the provincial level — and that had been harmonized-for the whole of Spain, France, and Portugal. With this, we were able to work directly with the provincial data and to make the calculations only once. However, this meant renouncing the possibility of making a more detailed analysis of the railway needs of the interior, which is something that was possible using the data for the judicial districts. With this in mind, we began working with these data and then, in a second phase, used the provincial data to include cross-border requirements in our analysis.

Feeding the gravity model with the data for Spain's judicial districts, in the way described, we were able to obtain an estimation of their potential for economic interaction. As a result, it was also possible to obtain an estimation of their need for interconnection. As we have already seen, any given pair of judicial districts $i, j$ is associated by the value $P_{i j}$. Our reading was based on the understanding that the larger the value of $P_{i j}$, the greater the priority to connect them. This enabled us to obtain an image of what the main priorities were for connecting the interior of Spain in 1860 .

When used with data for judicial districts in Spain, our model treats Spain as if it were an island. As a result, it is unaware of the need-which is also economic - to connect the country to Portugal and France. This is something we dealt with at a later stage. At the moment, we just work with interior connexions and, for the sake

11“The distance factor involved in the gravity and potential concepts has been a source of much debate. Empirical evidence from a number of sources suggests that the impact of distance is not uniform and that its relationship in the basic equations is not a simple inverse one, but rather one in which distance is raised to some power other than unity. A number of different exponents have been used in testing, with these ranging from 0.5 to 3 ." 

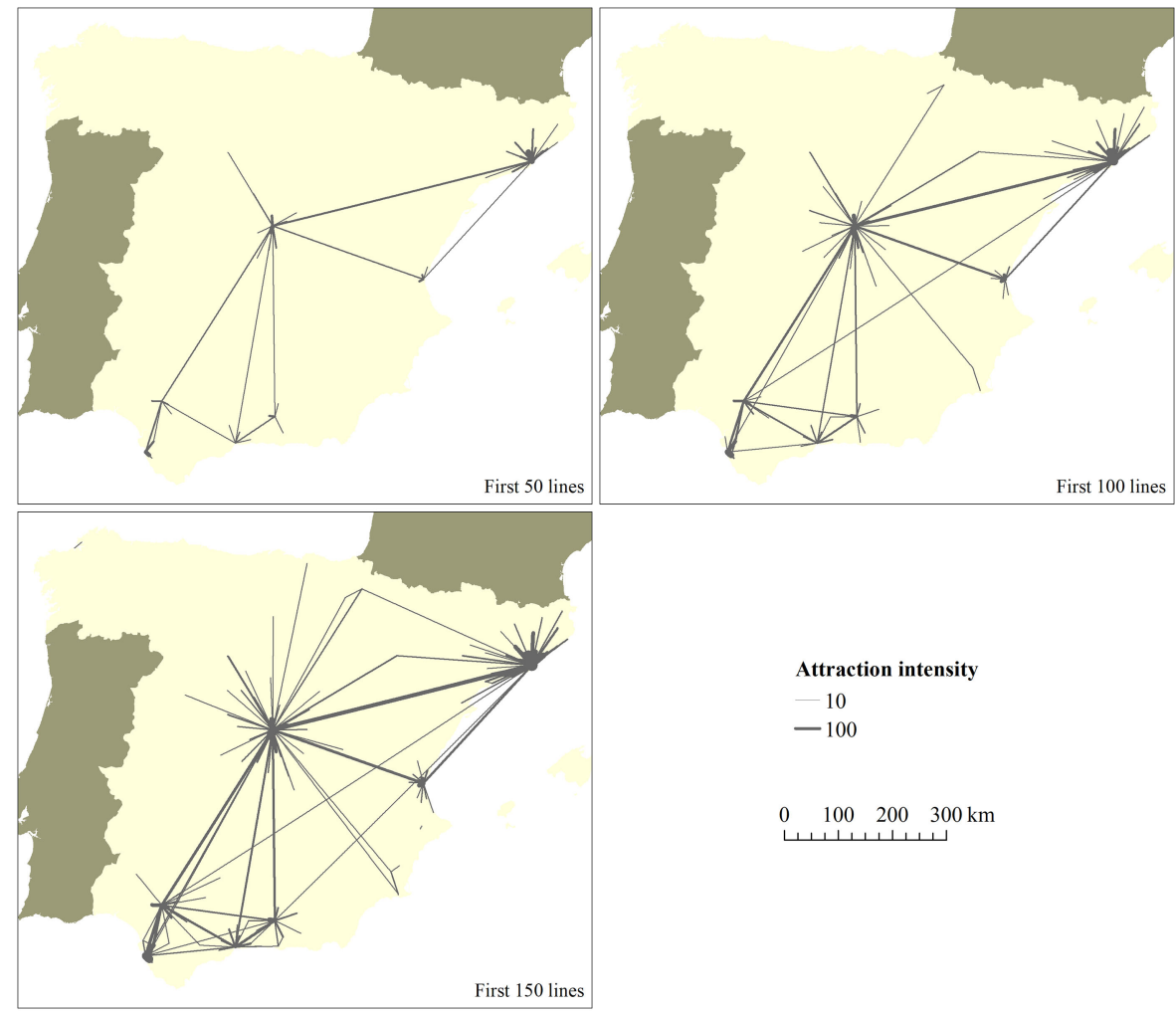

First 100 lines

Figure 4. Attraction intensity between judicial parties in Spain, 1860.

Source: Author computations.

of clarity, we will make our initial reading of the results at two different levels: the judicial district and long-distance levels. In other words, we first established which of Spain's judicial districts would require the most investment in transport and whose connectivity should be given the greatest priority. We then centered our analysis on determining which long-distance connections were most urgently required.

Figure 4 shows the first 50,100, and 150 priorities for connection. The thickness of each line represents the $P_{i j}$ of its connection: the thicker the line, the greater the priority of its construction. From the first image in figure 4 (50 highest priorities), we can make the following deductions: Catalonia and Andalucía were the autonomous communities that presented the greatest need for railway investment. In the former, the demand was completely centralist and granted an indiscutable hegemony to Barcelona. In Andalucía, however, there were four regions-Sevilla, Cádiz, Málaga, and Granada - that needed to be connected to one another without granting clear primacy to any of them. In the case of Madrid and Valencia, in a similar way to Catalonia, there was an evident attraction effect. The subsequent figures, which included more connections, strengthened our analysis and further underlined the centralist demands of Barcelona and Madrid. 
In the case of the long-distance connections, the following routes stand out (which we present in order of importance): Barcelona-Madrid, Andalucía (Sevilla)-Madrid, Valencia-Madrid, and Valencia-Barcelona. The figures showing the highest priorities also support the case for connections to Zaragoza-from both Barcelona and from Madrid-and between the capital and both Pamplona and Cartagena. The areas in the northeast of Spain-Galicia and Asturias-were completely forgotten by the results of our model. In our analysis, what stood out was the potential of both the regional connections and the long-distance ones, with respect to the four major poles: Barcelona, Madrid, Andalucía, and-a little further behind-Valencia.

In the next section we incorporate regions in neighboring countries into our calculations.

\section{Cross-Border Connections}

Our analysis would not have been complete without taking into account the effect that the presence of neighboring countries had on Spanish railway policy. Ideally, we would have liked to have had data for France and Portugal that were comparable with those used in the previous section, but they were not available. However, this apparent limitation - which forced us to work with more aggregated data relating to the provincial level - may not, in fact, have constituted a problem at all. For example, the construction of the Barcelona-Paris route would not have been designed with the sole purpose of connecting the municipality of Barcelona to París, but of connecting the Barcelona region in its widest sense. A journey of these characteristics could cause someone from the surrounding area to travel to Barcelona using a regional train (if there was one available) to use the route. Along these lines, we did not find any major problems when having to work with provinces and we even think that this may have provided us with some more representative results.

By again applying the gravity model, but this time studying only the cross-border connections, we found the priorities in table 2 .

The number of cross-border connections that a state could consider is, by necessity, limited and selective. We avoided offering a long list of priorities that would not have contributed very much to our analysis. At the same time, we sought to present several alternatives to the most urgently required connections. For this reason, we decided to limit to seven the number of connections shown between Spain and each of its neighboring countries.

To obtain a more complete image of Spain's railway needs in 1860 , we superimposed these lines upon those previously mentioned. As a result, we obtained the results shown in figure 4.

It is valid to highlight the fact that as we were working with different administrative units at the same time, we were not able to compare the interior connections with the cross-border ones. It was possible to rank the interior connections, on one hand, and the cross-border ones, on the other, but not to make any direct comparisons between the two. Our analysis did, however, allow us to take certain factors into consideration.

The first thing that we deduced was that, in the case of connections with France, Paris clearly monopolized the attraction. Even so, it made no sense to promote five 
different connections between Spain and Paris. In fact, our model also allowed us to deduce that the first incentives should have been given to the Barcelona-París connection and then, secondly, to that between Madrid and Paris. Moreover, Barcelona needed to be quickly connected to other cities in the south of France. This apparently made Barcelona the priority region to receive connections to the neighboring country.

In the case of Portugal, we were able to observe that the two highest-priority connections were between Andalucía and Lisbon. They were then followed by the Galicia-Porto and Madrid-Lisbon connections. Andalucía, Catalonia, and Galicia are all geographically privileged regions for commercial relations with neighboring countries. At the other extreme, we it is possible to deduce that the central position of Madrid within the Iberian Peninsula would undermine the economic interest in connecting it to France or Portugal, despite the high GDP of the Spanish capital. Paradoxically, what from an international perspective may constitute a problem - such as the centrality of Madrid and its distance from international bordersmay be an advantage in terms of interior connections. Madrid seems to make a good passing place for the majority of internal long-distance connections. It would therefore seem reasonable, for example, to pass through Madrid when traveling from Barcelona to Andalucía. This is not, however, captured by our model. The indicator that we have constructed therefore encounters a relevant problem when it comes to evaluating the economic viability of railway investment in a given judicial district because it only contemplates this judicial district as a possible point of origin or destination. It does not contemplate the possibility of this judicial district also being a very good potential passing place. This reflection led us to construct a second indicator that measures precisely how good a judicial district is as a passing place. This provided some results that, when combined with those previously mentioned, were able to enrich our analysis.

In the next section, we again limit our analysis to the strictly Spanish case, but this time to develop the second approach that we proposed.

\section{The Judicial District as a Passing Place}

In an intuitive way, we understood that, for any two districts $i, j$, a judicial district $k$ would be a good passing place if we did not have to make an excessive detour from our initial route $i, \rightarrow j$. Given that, in the long run, a state would want to create a network that would cover its whole territory, it is necessary, from the very startand before even beginning to build the most urgently needed routes- to have in mind a network that would be optimal for providing services to the whole country. Along these lines, the exercise proposed here was used to discover which judicial districts would make the best passing places-this was calculated taking into account their GVA - and, ultimately, their position within Spain.

This led us to create an indicator-see the supplementary appendix for the mathematical details-that could measure the suitability of each judicial district as a passing place. According to our results (see table 3), Madrid was clearly the best center for national distribution.

This is because, of all possible combinations (with just one stop) that connect every single judicial party with the rest (104.653 possibilities), Madrid ends up being 
Table 2. Main connections with France and Portugal, in order of priority

\begin{tabular}{cccc}
\hline Connections between Spain and France & \multicolumn{2}{c}{$\begin{array}{c}\text { Connections between Spain and } \\
\text { Portugal }\end{array}$} \\
\hline 1 & Barcelona - Paris & 1 & Sevilla - Lisbon \\
\hline 2 & Madrid - Paris & 2 & Cádiz - Lisbon \\
\hdashline 3 & Valencia - Paris & 3 & Coruña - Porto \\
\hdashline 4 & Granada - Paris & 4 & Madrid - Porto \\
\hline 5 & Zaragoza - París & 5 & Badajoz - Lisbon \\
\hdashline 6 & Barcelona - Marseille & 6 & Madrid - Lisbon \\
\hline 7 & Barcelona - Montpelier & 7 & Coruña - Braga \\
\hline
\end{tabular}

Source: Author computations.

Table 3. Best judicial parties as a passing place

\begin{tabular}{lccc}
\hline & Passing place & \% passing place & GVA $^{*}$ \\
\hline Madrid & 77.842 & 74,4 & 252,0 \\
\hline Valencia & 32.376 & 30,9 & 87,6 \\
\hline Valladolid & 28.621 & 27,3 & 30,1 \\
\hline Sevilla & 27.228 & 26,0 & 114,9 \\
\hline Granada & 25.711 & 24,6 & 77,3 \\
\hline Barcelona & 24.650 & 23,6 & 199,6 \\
\hline Segovia & 24.613 & 23,5 & 17,7 \\
\hline Zaragoza & 22.942 & 21,9 & 43,9 \\
\hline Chinchón & 22.473 & 21,5 & 13,8 \\
\hline Alcala de Henares & 21.761 & 20,8 & 13,6 \\
\hline Toledo & 20.971 & 20,0 & 12,8 \\
\hline
\end{tabular}

Source: Author computations.

"acceptable" (e.g., there is no need to make an excessive detour) as a passing place 77.842 of times if one wishes to connect all judicial parties with the rest (except from Madrid). This is explained by the economic weight of Madrid and its advantageous position within the Iberian Peninsula. As one can see from table 3, the judicial party of Barcelona, whose GVA is approximately an 80 percent relative to Madrid's, only appears as an acceptable passing place 23.5 percent of all possible combinations, three times less compared to Madrid. In short, these results highlight that not only GVA or any other economic measure is relevant to determine transport policies but also the relative location of those economic nuclei matter as to decide where to invest.

From both an economic and a geographical point of view, it therefore made sense to construct quite a centralist network. The regions of Catalonia and Andalucía that 
-as we have previously seen-were the ones that would have required the most investment in regional railway infrastructure and were relatively good passing places but did not particularly stand out for this quality. In this sense, their respective geographical positions within the peninsula would have worked against them, even though they were the best regions for establishing contacts with neighboring countries.

In a similar way, the area to the northeast of Madrid — and especially Zamora, Valladolid, and Palencia - appeared to be good passing places. Furthermoreand bearing in mind the results of the previous exercise-we concluded that these regions stood out, not so much on account of their economic weight, but rather for their privileged positions. Their strategic position, half-way between the center of Spain and Galicia and Asturias, respectively, combined with the relatively good GVA values of their regions make them potential stopping points that stood out above those in other regions with comparable levels of GVA.

In the next section, we make an analysis of economic policy and study the extent to which Spain's railway policy was correct based on the empirical evidence presented by the quantitative results obtained in this section.

\section{Analysis of the Results}

So far, we have presented the initial context for Spain's railway policy and the state's priorities for establishing connections. We have also presented an estimation of which lines, connecting both the internal and external territory, were of greatest importance according to our gravity model. In this section, we analyze whether the railway policy promoted by the state could have gone against the economic needs of the country. Here, it needs to be underlined that we only study mediumand long-distance railway connections, as these were the ones that best allow us to compare our results. Additionally, these are also the ones that the state showed most interest in building during the initial process of railway construction.

Without sacrificing the precision of our analysis, we propose an initial comparison of the state's priorities for connection based on the set of railway lines approved by the Spanish Congress in 1854 and the railway system that was constructed in the year 1860 . The former were generally respected when the network was built, with the most important exception being the line between Barcelona and Valencia. Generally speaking, our model suggests that the morphology of the network that the state supported corresponded quite well to meeting the alleged economic needs of the country.

A finer analysis of the internal connections shows the following: our model establishes the priority lines as those running from Madrid to Barcelona, Valencia, Andalucía (Sevilla, Cádiz, Málaga), and Cartagena, and also the one from Barcelona to Valencia. When we compare this set of lines with that approved by the Spanish Congress, it is possible to appreciate an important degree of similarity. The most relevant discrepancies arose for two main reasons: the first was that our model did not incorporate any strategic considerations or of equity or accessibility from the whole of the territory. It only considered railway lines constructed between the regions that most "attracted" each other from an economic point of view. It is 
precisely for this reason that the calculations made using our model did not establish any internal connections of interest toward the northwest part of the Iberian Peninsula. The considerations that could be used to justify the state's interest in constructing connections from Madrid to Galicia and Asturias were therefore not purely economic. Other motives held sway, such as the need to structure the national territory and to gain rapid access to the Atlantic coast. The second discordant element was that although the Barcelona-Valencia connection was not one of the highest priority options in the final layout of lines approved by the Spanish Congress in 1854, our model was able to identify the urgent need to connect these two cities. Even so, it should also be underlined that the state very quickly changed its point of view regarding this connection, as only five years later it began to construct this line and had already finished it a decade later. It is similarly necessary to note the great interest that the state had in this particular stretch of track, as its construction was heavily subsidized.

The same comparative exercise conducted in relation to the external connections suggests that - in contrast to what we observe for internal connections-the political will to connect the capital to neighboring countries is not entirely justified by the priorities established by our model. In the case of France, the majority of the political voices, as well as those from other social circles, gave priority to the Madrid-Paris connection over any other. This was clearly shown in the scheme of lines approved by Congress in 1854, which projected the Madrid-Irún line and initially left to one side the connection between Barcelona and Paris. The latter is, however, the line that our model suggests as the most urgent one, as can be seen in Table 2. Even so, it also needs to be explained that although the Madrid-Irún connection was constructed faster, the state still only took about a decade to connect Barcelona to France. The case of Portugal offers some similar conclusions, but with different actors involved. Although, also in this case, priority was given to the Madrid-Lisbon connection, our model suggests that before connecting the capital, the highest priority in terms of economic profitability would have been to connect certain cities in Andalucía (such as Sevilla and Cádiz) to the Portuguese capital. In addition, our model also highlights the medium-distance connection between Porto and Coruña as deserving greater priority than uniting the capitals of the two countries, but always based on the criterion of attraction between economic nuclei.

In light of the previously presented interpretations, it is impossible to deduce one single, or clearly evident narrative. The reading that we have drawn for internal connections is that the priority of the state to connect the capital to the most important points in the kingdom did not seem to run contrary to what could be regarded as the economic needs of the country at the time. This is explained by the economic weight of Madrid, the geographical distribution of economic activity in the rest of Spain's territory and the advantageous location of the capital, which gave it added importance as an excellent center of distribution for the different regions of the country.

That said, our reading is different for the case of the external connections. The results obtained when applying our model suggests that for external connections there could certainly have been a certain "capital effect." This manifested itself in the promotion of lines of lesser economic interest that were constructed with the purpose of connecting the capital with París and Lisbon before other regions received such connections. 


\section{Conclusions}

The initial period of Spanish railway network construction is often the object of criticism due to its radial structure, which was centered on Madrid. This opinion tends to be based on the argument that a centralizing, political project was given priority over economic interests and achieving the cohesion of the whole territory.

Our analysis of existing literature confirms that there was a clear political interest in connecting Madrid to the rest of the regions of Spain and that this priority shaped the morphology of the national rail network, giving it a predominantly radial structure during the initial stages of its construction. Even so, it seems unfair to deduce-as some authors have done- that this radial structure went against the economic needs of the country. This document also suggests that other priorities - relating to the redistribution of resources, strategic considerations, and state-building —also influenced the initial design of Spain's railway network. With specific reference to centralization, we argue that this could - at least in part-have been aimed at strengthening the presence of the state (which was, at that time, very limited) throughout the whole territory and at promoting the process of state-building within Spain. Although the idea of the state constructing a transport network that would serve its political interests relating to its consolidation of power could be criticized as a criterion for railway policy, it could be that such a structure facilitated the task of introducing, promoting, and monitoring of a series of common policies and regulations for the whole national territory.

The central contribution of our article consists of shedding some light on the debate about the extent to which the initial radial morphology of the network was, or was not, justifiable from an economic point of view. The quantitative results that we obtained point to the fact that, in general terms, the centralist network that the state imposed during the first phase of railway construction did not significantly differ from the priority connections that would have been established following strictly economic criteria. In other words, if the state had limited its involvement to constructing a network based on lines following economic criteria (of the type that our model suggests), the resulting railway system would have been notably similar to that which was finally built. This can mainly be explained by the distribution of economic activity within Spain at the time and to the relative advantage that certain regions had given their geographic locations on the Iberian Peninsula. From this point of view, Madrid was the best-positioned nucleus to act as a center for distribution, given its central location and economic weight.

The results that we obtained question two of the actions in the state-planned network: firstly, the state promoted connecting Madrid to two of the most disfavored regions in the country (Galicia and Asturias); these routes should not have received priority according to our model. This does not imply that these stretches were necessarily the product of erroneous decisions in terms of railway policy, but it does show that the state promoted rail routes for other reasons (including access to the Atlantic coast, equity, and territorial cohesion) than providing connections to economically important parts of the interior. Secondly, it seems that, with respect to the crossborder connections, there could have been a certain "capital effect." This gave priority to connecting Madrid to the capitals of the neighboring countries before establishing the routes suggested by our model, which could have been of even greater immediate economic interest according to our model (e.g., the Barcelona-Paris route and connections between some Andalucian cities and Lisbon). 
Finally, in general terms, the empirical evidence suggests that the radial configuration with which the Spanish railway system was originally conceived arose in quite a natural way due to the distribution of economic activity in Spain. To this we must add the relative advantage that Madrid derives from its geographic position. Although the design of the Spanish railway network was not based on exclusively economic criteria, our results allow us to question the popularly held view that due to political influences in the design process its radial morphology did not satisfy the economic needs of the country.

Acknowledgments. Frank Beltran for providing the data on occupations for Spain (1860). And to Pere Pascual for his advice. Funding: University of Lleida and Spanish Ministry of Science.

Supplementary material. To view supplementary material for this article, please visit https://doi.org/10. $1017 /$ ssh.2021.3

\section{References}

Alvarez-Palau, Eduard, Xavier Franch and Jordi Martí-Henneberg (2013) "Evolution of the territorial coverage of therailway network and its influence on population growth: The case of England and Wales, 1871-1931". Historical Methods: A Journal of Quantitative and Interdisciplinary History 46 (3): 175-91.

Anderson, Theodoro R. (1956) "Potential models and the spatial distribution of population." Papers in Regional Science 2 (1): 175-82.

Ardant, Gabriel and Charles Tilly (1975) "Financial Policy and Economic Infrastructure of Modern States and Nationsin: Ardant, Gabriel”. The Formation of National States in Western Europe. Vol. 8. Princeton University Press.

Artola, Miguel (1978) Los ferrocarriles en España: 1844-1943. Servicio de estudios del Banco de España.

Badia-Miró, Marc, Jordi Guilera Rafecas, and Pedro Lains (2012) "Reconstruction of the regional GDP of Portugal, 1890-1980.” Documents de treball 12 (280): 1-18.

Barquín, Rafael (2009) “El diseño de la red ferroviaria y los intereses agrícolas.” Paper presented at the V Congreso de Historia Ferroviaria, Palma, October 14.

Barquín, Rafael, Pérez, Pedro, and Sanz, Basilio (2012) "La influencia del ferrocarril en el desarrollo urbano español (1860-1910): Railways' influence in the Spanish urban development." Revista de Historia Economica-Journal of Iberian and Latin American Economic History 30 (3): 391-416.

Bel, Germà (2011) "Infrastructure and nation building: The regulation and financing of network transportation infrastructures in Spain 1720-2010.” Business History (53): 688-705.

Beltrán Tapia, Francisco (2016) “Common lands and economic development in Spain.” Revista de Historia Economica-Journal of Iberian and Latin American Economic History 34 (1): 111-33.

Beltrán Tapia, Francisco, Alfonso Díez-Minguela, and Julio Martinez-Galarraga (2018) “Tracing the evolution of agglomeration economies: Spain, 1860-1991.” The Journal of Economic History 78 (1): 81-117.

Carrothers, Gerald A. P. (1956) "An historical review of the gravity and potential concepts of human interaction.” Journal of the American Institute of Planners 22 (2): 94-102.

Casares, Alonso (1973). Estudio histórico-económico de las construcciones ferroviarias españolas en el s. XIX. Vol. 10. Madrid: Instituto Nacional de Administración Pública.

Combes, Pierre Phillipe, Miren Lafourcade, Jacques-François Thisse, and Jean-Claude Toutain (2011) "The rise and fall of spatial inequalities in France: A long-run perspective." Explorations in Economic History 48 (2): 243-71.

Cuéllar, Domingo (2002) "Política de obras públicas y políticas liberales. El Ministerio de Fomento (18511874)." TST: Transportes, Servicios y telecomunicaciones (2): 43-69.

- (2007) "El ferrocarril en España, siglox XIX y XX: una visión a largo plazo.” Madrid: Universidad Autónoma of Madrid. Department of Economic Analysis.

De Block, Greet (2011) "Designing the nation: The Belgian railway project, 1830-1837." Technology and Culture 52 (4): 703-32. 
Del Peral, M. (1979) “Los orígenes de la política ferroviaria en España (1844-1877),” in Miguel Artola, Los ferrocarriles en España: 1844-1943. Vol. 1. Madrid: Servicio de Estudios del Banco de España. Los ferrocarriles en España: 50-170.

Elden, Stuart (2007) “Governmentality, calculation, territory." Environment and Planning D: Society and Space 25 (3): 562-80.

Enflo, Kerstin, Eduard Alvarez-Palau and Jordi Martí-Henneberg (2018) “Transportation and regional inequality: The impact of railways in the Nordic countries, 1860-1960.” Journal of Historical Geography 62: $51-70$.

Equipo Urbano (1972) "Simulación de una red de transportes. El caso de los ferrocarriles españoles." Revista de geografia 6 (1): 34-54.

Esteban-Oliver, Guillermo (2017) “La distribución geográfica de la actividad económica y de la industria en España: un análisis a nivel de partido judicial, en base al censo de 1860.” Biblio3W. Revista Bibliográfica de Geografía y Ciencias Sociales (22): 1-39.

Ferri, Marc (2015) El ejército de la paz: Los ingenieros de caminos en la instauración del liberalismo en España (1833-1868). Universitat de València.

Flora, Peter (1973) "Historical processes of social mobilization: Urbanization and literacy, 1850-1965," in Shemu el Noah Aizenshtadt and Stein Rokkan (eds.) Building States and Nations: Models and Data Resources. Sage: 213-58.

(2016) State, Economy, and Society in Western Europe, 1815-1975. Palgrave Macmillan.

Frax, Esperanza (1996) "Las leyes de bases de obras públicas en el siglo XIX." Revista de estudios políticos (93): 513-28.

Gómez Mendoza, Antonio (1982) Ferrocarril y cambio económico en España. Madrid: Alianza Editorial.

Hernández, Telesforo M., and Sebastià García Martínez (1983) Ferrocarriles y capitalismo en el País Valenciano: 1843-1879. Ayuntamiento de Valencia, Delegación municipal de cultura.

Herranz-Loncán, Alfonso (2006) "Railroad impact in backward economies: Spain, 1850-1913." The Journal of Economic History 66 (4): 853-81.

Hirsch, Jean Pierre (2003) "Saint-simonisme et organisation du territoire. Sur un programme de 1832." Revue du Nord (4): 863-72.

Martí-Henneberg, Jordi (2013) "Europeanintegration and national models for railway networks (18402010)". Journal of Transport Geography 26: 126-138.

Martinez-Galarraga, Julio (2012) “The determinants of industrial location in Spain, 1856-1929." Explorations in Economic History 49 (2): 255-75.

Martínez-Galarraga, Julio, Joan R. Rosés, and Daniel A. Tirado (2015) “The long-term patterns of regional income inequality in Spain, 1860-2000.” Regional Studies 49 (4): 502-17.

Millward, Robert (2004) "European governments and the infrastructure industries, c. 1840-1914." European Review of Economic History 8 (1): 3-28.

Mitchell, Allan (2000) The Great Train Race: Railways and the Franco-German Rivalry, 1815-1914. Berghahn books.

Mojica, Laia, and Martí-Henneberg, Jordi (2011) "Railways and population distribution: France, Spain, and Portugal, 1870-2000.” Journal of Interdisciplinary History 42 (1): 5-28.

Morillas-Torné, Mateu (2014) "El ferrocarril de vía estrecha en España, 1852-2010. El papel de la intermodalidad y de la demanda en su construcción y estado actual." Scripta Nova: Revista electrónica de geografía y ciencias sociales 18 (485): 463-99.

Muñoz, Miguel, and Javier Vidal (2001) “Los ferrocarriles en la historiografía española.” Transportes, servicios y telecomunicaciones (1): 81-111.

Nadal, Jordi (1975) Elfracaso de la Revolución Industrial en España. Barcelona: Ariel.

__ (1982) "El fracaso de la revolución industrial en España: 1830-1914," in Carlo M. Cipolla (ed.) Historia económica de Europa. Barcelona: Ariel: 178-272.

Olmedo Gaya, Ana Isabel (2001) "Estudio histórico del ferrocarril desde la perspectiva de sus normas reguladoras." Paper presented at the II Congreso De Historia Ferroviaria, Aranjuez, February 7.

Ormaechea, Angel María (1989) Ferrocarriles en Euskadi: 1855-1936. Eusko Trenbideak-Ferrocarriles Vascos.

Ortúñez, Pedro Pablo (2016) "Railway financing before nationalization: Insights into the history of water, transport, and telecommunications," in Youssef Cassis, Giuseppe De Luca, and Massimo Florio Youssef Cassis (eds.) Insights into the History of Water, Transport. Oxford University Press: 218-39. 
Pablo-Martí, Federico, Ángel Alañón-Pardo, and Angel Sánchez. "Complex networks to understand the past: the case of roads in Bourbon Spain." Cliometrica (2020): 1-58.

Pascual, P. (2017) El ferrocarril a Catalunya (1848-1935). Una historia de la seva explotació. Eumo.

Pereira, Hugo Silveira (2017) "The technodiplomacy of Iberian transnational railways in the second half of the nineteenth century." History and Technology 33 (2): 175-95.

Pereira, Hugo Silveira, and S. M. Peto (2012) "Building a national railway network: Portugal second half of the 19th century." Paper presented at 37th Annual Economic and Business Historical Society Conference, Las Vegas, April 26.

Philbrick, A. T. (1973) "A short history of the development of the gravity model." Australian Road Research 5 (4): 40-52.

Pinheiro, Magda (1995) “L'Histoire d'un divorce: l'integration des Chemins de Fer Portugais dans le Réseau Ibérique," in Michèle Merger, Les réseaux européens transnationaux XIXe-XXe siècles: quels enjeux. Nantes: Ouest Editions: $337-46$.

Prados de la Escosura, Leandro, and Isabel SanzVillarroya (1998) Historical comparisons of income: a short-cutapproach. Seminar at Carlos III University, Madrid.

Rosés, Joan, Julio Martínez-Galarraga, and Daniel Tirado (2010) "The upswing of regional income inequality in Spain (1860-1930)." Explorations in Economic History 47 (2): 244-57.

Stewart, John Q. (1941) “An inverse distance variation for certain social influences." Science 93 (2404): 89-90.

Teichova, Alice, and Herbert Matis, eds. (2003) Nation, State and the Economy in History. Cambridge University Press.

Tirado, Daniel, Alfonso Díez-Minguela, and Julio Martinez-Galarraga (2016) "Regional inequality and economic development in Spain, 1860-2010." Journal of Historical Geography (54): 87-98.

Tortella, Gabriel (1973) Los orígenes del capitalismo en España: banca, industria y ferrocarriles en el siglo XIX. Tecnos.

Vidal, Esther (1999) Fronteras y ferrocarriles: génesis, toma de decisión y construcción de los carriles transpirenaicos (1844-1929). Universitat de Lleida.

Wais, Francisco (1974) Historia general de los ferrocarriles españoles. Nacional.

Wündsch, Björn (2016) "Railway financing," in Youssef Cassis, Giuseppe De Luca, and Massimo Florio Youssef Cassis (eds.) Insights into the History of Water Transport. Oxford University Press: 240-52.

Zipf, George. K. (1946) "The P1P2/D hypothesis: On the intercity movement of persons." American Sociological Review 11 (6): 677-86.

Jaume Martí-Romero holds a bachelor's degree in economics (2013) at Universitat Pompeu Fabra and graduate degree in economics and finance at the Barcelona Graduate School of Economics (2014). Currently working at the Barcelona Chamber of Commerce.

Adriá San José holds a degree in mathematics and another one in physics. He obtained a postgraduate course in data science and has been working ever since in the field of data-driven mathematical modeling. He has extensively collaborated with the human geography research group at the University of Lleida and is currently working at the Barcelona Institute for Global Health. He recently published in Frontiers in Digital Humanities. (https://www.frontiersin.org/articles/10.3389/fdigh.2017.00019/full).

Jordi Martí-Henneberg is full professor of human geography at the Universitat de Lleida (Spain), teaching Geography of Europe from 1990. He graduated in history and geography and earned a $\mathrm{PhD}$ at the University of Barcelona. He has been invited as a visiting scholar at Cambridge University (2006, 2011, and 2016). He has also been ICREA-Academia researcher for the period 2013-2018 and leads several research projects, mostly funded by the European Union.

Cite this article: Martí-Romero, Jaume, Adrià San-José, and Jordi Martí-Henneberg (2021) “The Radiality of the Railway Network in Spain during its Early Stages (1830-67): An Assessment of its Territorial Coherence," Social Science History 45:363-389. doi:10.1017/ssh.2021.3 